\title{
Centropages aegypticus sp. nov., a new calanoid copepod from the northern Red Sea
}

\author{
MOHSEN M. EL-SHERBINY ${ }^{1}$ AND HIROSHI UEDA ${ }^{2}$ \\ ${ }^{1}$ Marine Science Department, Faculty of Science, Suez Canal University, Ismailia-41522, Egypt, ${ }^{2}$ USA Marine Biological Institute, \\ Kochi University, 194 Inoshiri, Usa, Tosa, Kochi, 781-1164, Japan
}

\begin{abstract}
A new species of calanoid copepod, Centropages aegypticus sp. nov. collected from the Egyptian coasts of the northern Red Sea is described. This species is unique in having two pointed conical processes on the dorsal surface of cephalosome in both sexes, female genital compound somite with irregular-surface outline of the right swelling part and transverse dorsolateral row of spinules on the left side, 2-segmented exopod of the female leg 5, asymmetrical medial processes of the female leg 5 , of which the left one is longer and medially-curved and the right one with oblique row of thick spinules, and a club-shaped medial seta on the third exopodal segment of the male leg 5. The new species is similar to C. tenuiremis, but is not assigned to the same species group as the latter species or to any other groups.
\end{abstract}

Keywords: calanoid Copepoda, Centropages aegypticus, new species, taxonomy, Red Sea

Submitted 3 February 2007; accepted 5 November 2007

\section{INTRDDUCTIDN}

Species of the genus Centropages Krøyer, 1849 have wide distribution from temperate to tropical and from coastal brackish to oceanic waters. The importance of this genus is well documented in the literature as a food source for fish (Brodsky, 1950; Chen \& Zhang, 1965). Species of this genus are distributed in the epipelagic waters (Vervoort, 1964; MacKinnon \& Kimmerer, 1988; MacKinnon \& Dixon, 1994; BradfordGrieve, 1999; Bradford-Grieve et al., 1999). To date, seven species have been recorded from the Red Sea (Halim, 1969; Razouls, 1995), namely, C. calaninus Dana, 1849, C. elongatus Giesbrecht, 1896, C. furcatus (Dana, 1849), C. gracilis (Dana, 1849), C. orsinii Giesbrecht, 1889, C. ponticus Karavaev, 1894 and C. violaceus (Claus, 1863). In this paper, a new species of Centropages collected from the neritic water of the Sharm El-Sheikh area, in the northern Red Sea is described.

\section{MATERIALS AND METHDDS}

Plankton samples were collected by horizontal tows of a plankton net ( $40 \mathrm{~cm}$ in mouth diameter, $100-\mu \mathrm{m}$ mesh) from a small, shallow and semi-enclosed bay called Sharm El-Maya located at the entrance of Sharm El-Sheikh city, the northern Red Sea $\left(27^{\circ} 51^{\prime} 39^{\prime \prime} \mathrm{N} 34^{\circ} 17^{\prime} 53^{\prime \prime} \mathrm{E}\right.$; water depth $2.5 \mathrm{~m}$ at the sampling point) in 2000 and 2001. This bay was used for about 20 years as a local port and a park for fishing and tourist diving boats. Its salinity yearly ranged between 40.5 and 41.5 psu, temperature between 22.7 and $30.9^{\circ} \mathrm{C}$, and chlorophyll- $a$ between 0.18 and $1.5 \mathrm{mg} \mathrm{m}^{-3}$ (El-Sherbiny, 1997; Aamer et al., 2006).

The samples were fixed immediately after collection in 5\% buffered formalin seawater. Specimens of the new species were

Corresponding author:

M.M. El-Sherbiny

Email: mohsenrussia@yahoo.com sorted out of the samples and then preserved in $70 \%$ alcohol. The specimens were dissected in lactophenol and examined with a differential interference microscope (Nikon, E6oo). All drawings were made with the aid of a camera lucida and the measurements with an ocular micrometer. The terminology used follows Boxshall \& Husley (2004). The type specimens are deposited at the National Science Museum, Tokyo (NSMT).

\section{SYSTEMATICS}

Family CENTROPAGIDAE Giesbrecht, 1892 Genus Centropages Krøyer, 1849 Centropages aegypticus sp. nov.

(Figures 1-4; Table 1)

\section{Type material}

Holotype: 1 adult female, $1.70 \mathrm{~mm}$, completely dissected and mounted on three glass slides [NMST-Cr 16880].

Allotype: 1 adult male, $1.58 \mathrm{~mm}$, partly dissected and mounted on two glass slides [NSMT-Cr 16881].

Other paratypes: 17 females (body length: $1.50-1.67 \mathrm{~mm}$, mean $\pm \mathrm{SD}=1.62 \pm 0.057 \mathrm{~mm}$ ) and 13 males (body length: $1.50-1.70 \mathrm{~mm}$, mean $\pm \mathrm{SD}=1.62 \pm 0.058 \mathrm{~mm}$ ) whole specimens in $70 \%$ ethanol [NSMT-Cr 16882].

The holotype and allotype specimens were collected on 22 June 2000 and other paratypes were on collected 27 June 2001. All type specimens were collected by M.M. El-Sherbiny.

\section{Description}

FEMALE (HOLOTYPE)

Body (Figure 1A) robust, prosome plump, widest at posterior border of first pediger; prosome about 2.5 times as long as urosome; cephalosome distinctly separate from first pediger, with two pointed conical processes mid-dorsally and small 

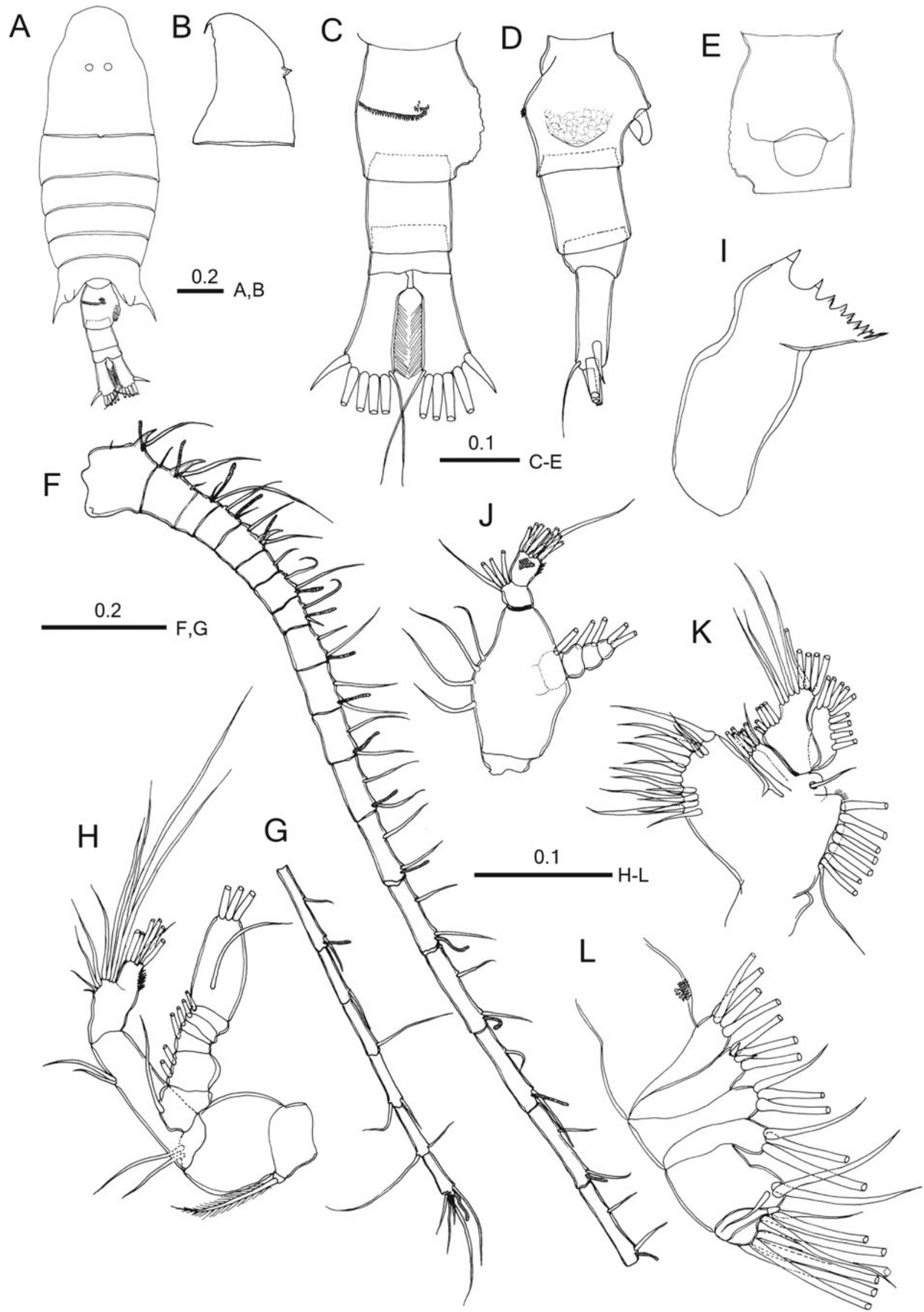

Fig. 1. Centropages aegypticus sp. nov. female (holotype). (A) Habitus, dorsal view; (B) cephalosome, lateral view; (C) urosome, dorsal view; (D) urosome, lateral view; (E) genital compound somite, ventral view; $(F-G)$ antennule; (H) antenna; (I) mandibular gnathobase; (J) mandibular palp; (K) maxillule; (L) maxilla. Scale bars in $\mathrm{mm}$ 
A

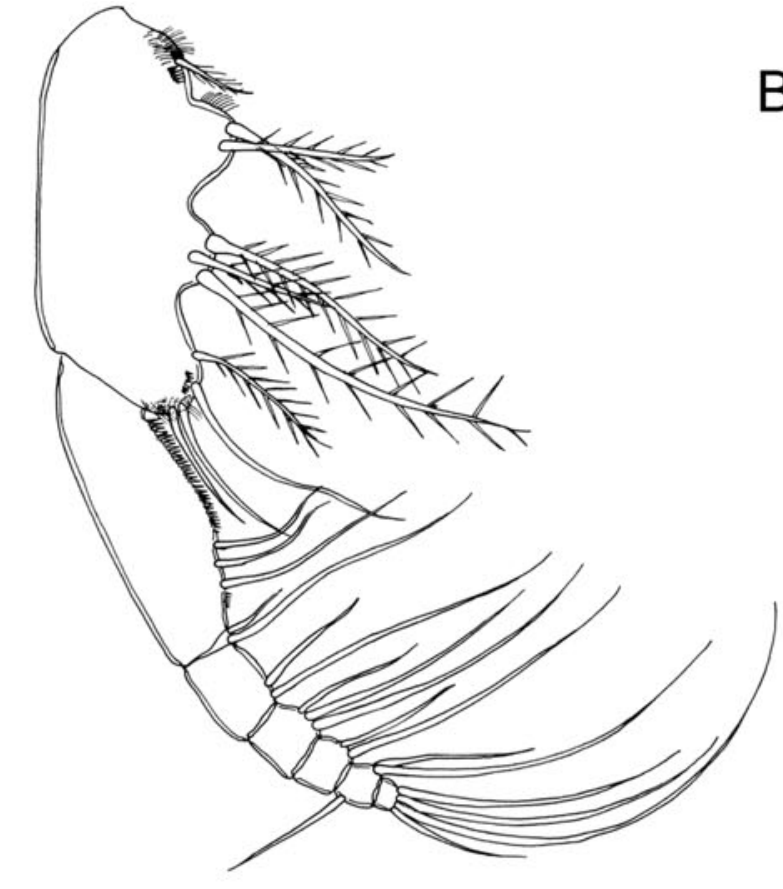

D

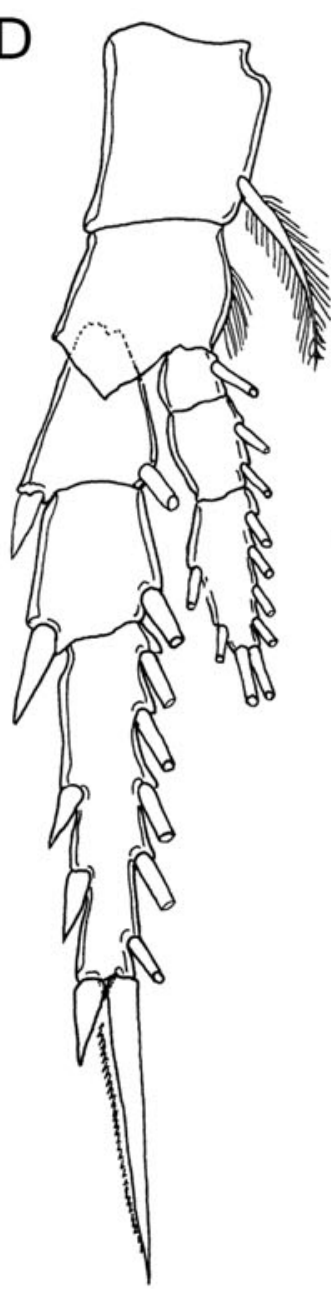

$\mathrm{E}$
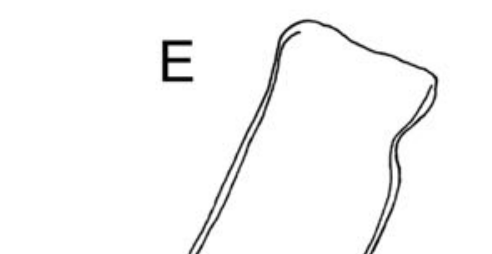

r

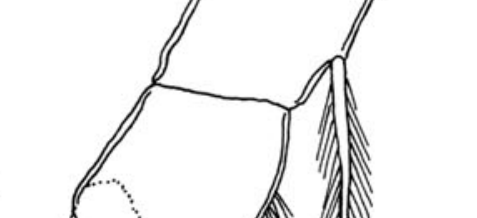

B

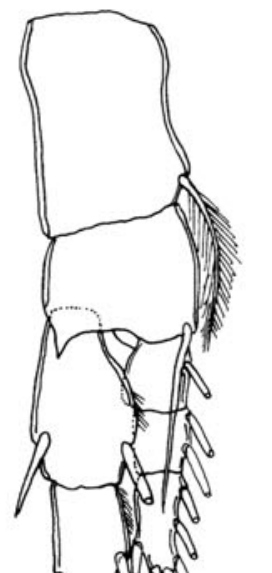

C
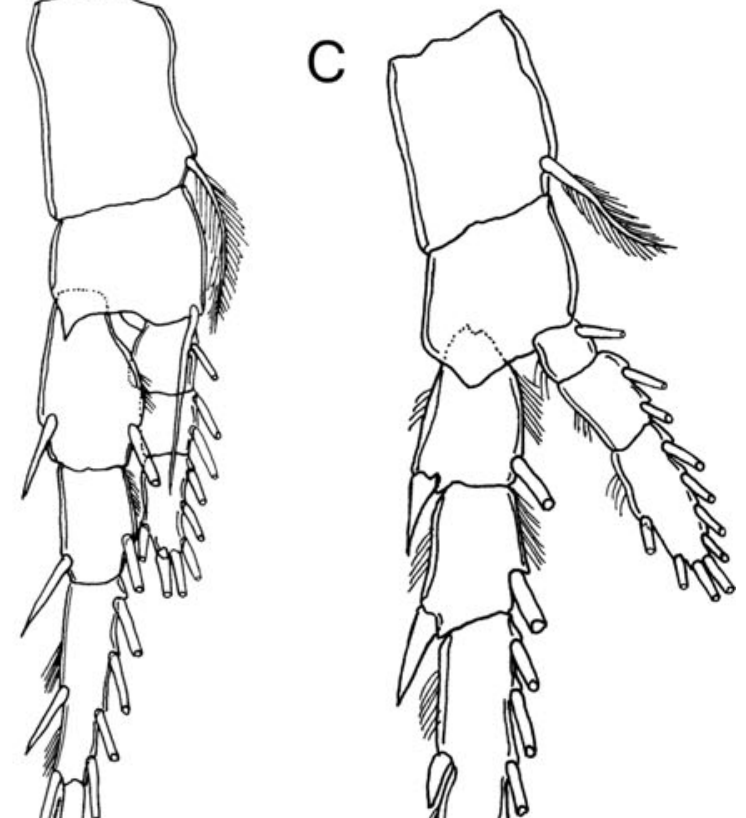

$\mathrm{F}$
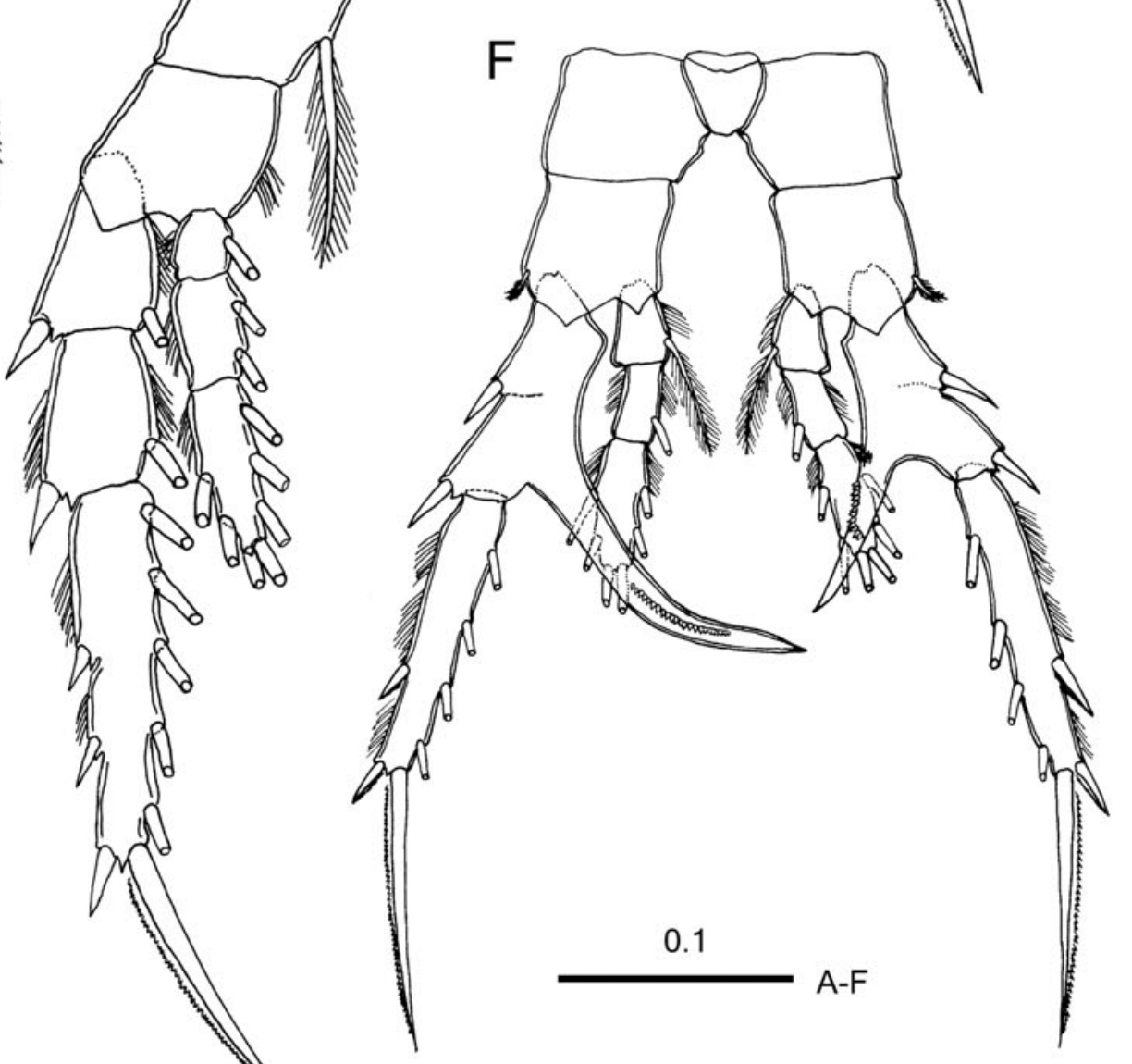

Fig. 2. Centropages aegypticus sp. nov. female (holotype). (A) Maxilliped; (B) leg 1; (C) leg 2; (D) leg 3; (E) leg 4; (F) leg 5. Scale bars in mm. 


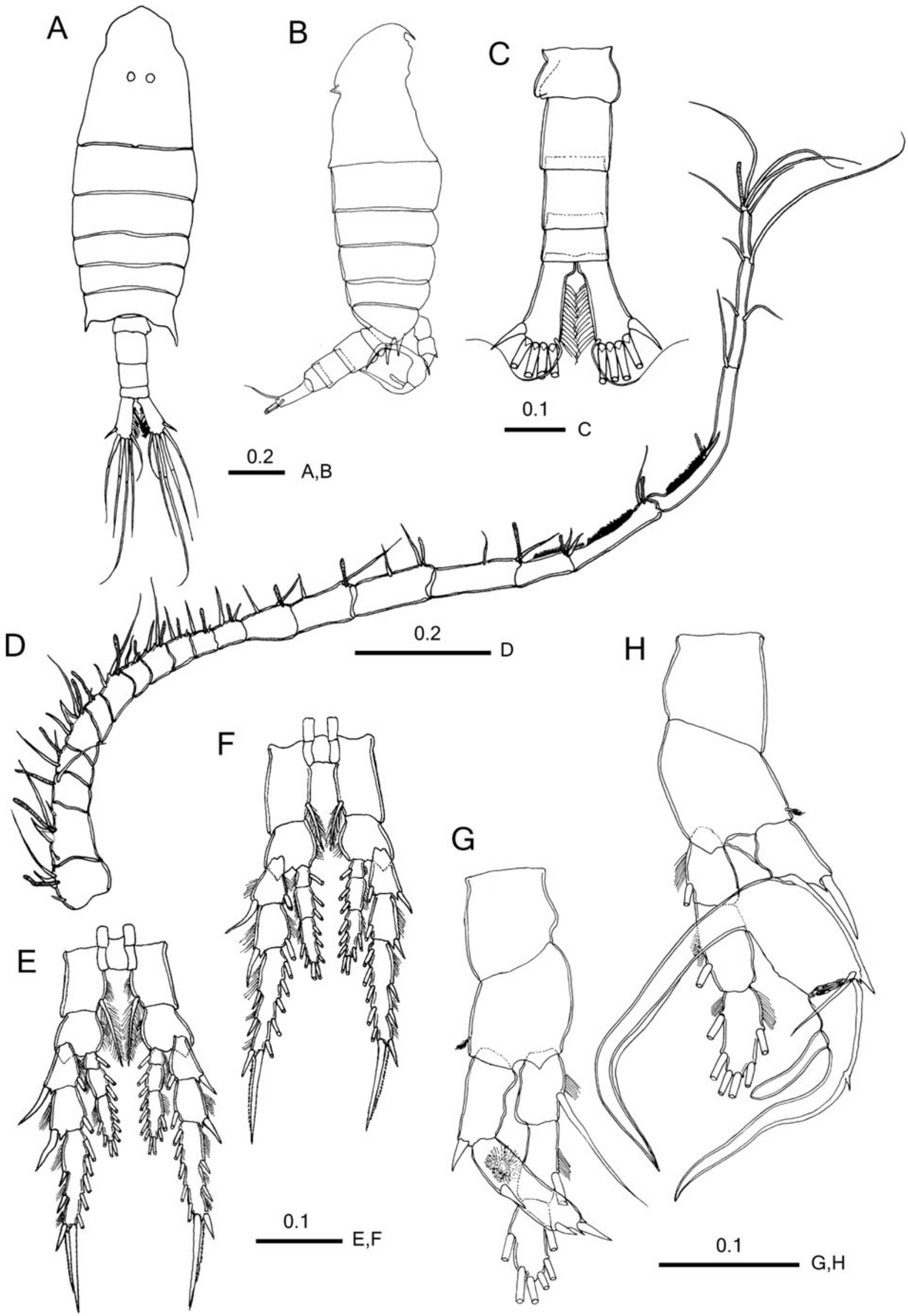

Fig. 3. Centropages aegypticus sp. nov. male (allotype). (A) Habitus, dorsal view; (B) habitus, lateral view; (C) urosome, dorsal view; (D) right antennule; (E) leg 3; (F) leg 4; (G) left leg 5, posterior view; (H) right leg 5, posterior view. Scale bars in $\mathrm{mm}$. 


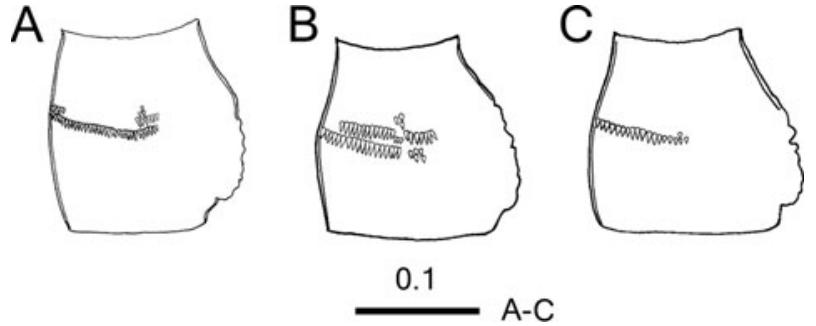

Fig. 4. Centropages aegypticus sp. nov. (A-C) Variations in the female genital compound somite. Scale bar in $\mathrm{mm}$.

knob on posterodorsal median border (Figure $1 \mathrm{~A} \& \mathrm{~B}$ ); fifth pediger asymmetrical, produced posteriorly into wing-like lappets, each terminating with acute process; right process directed backward, nearly reaching posterior border of genital compound somite, slightly longer than left process; left process directed more laterally than right one (Figure 1A). Rostrum (Figure $1 \mathrm{~B}$ ) bearing pair of long filaments with broad bases. Urosome (Figure $1 \mathrm{C}, \mathrm{D}$ ) three free somites. Genital compound somite (Figure $1 \mathrm{C} \& \mathrm{E}$ ) asymmetrical, with irregular surface outline swelling on right side and two transverse rows of spinules at midlength, anterior short row of them dorsally and posterior long one dorsolaterally on left side; genital operculum (Figure $1 \mathrm{E}$ ) located half way along ventral surface. Second free urosomite symmetrical; anal somite very small and symmetrical; caudal rami symmetrical and approximately 3.5 times as long as wide.

Antennule (Figure $1 \mathrm{~F} \& \mathrm{G}$ ) 24-segmented, when extended exceeds the caudal rami by the last four segments, reaching half way along longest caudal setae; first, second and fifth segments each with prominent spine almost fused with segment. Fusion pattern and armature elements as follows: I $(1)=2+$ aesthetasc(ae) + spine(sp), II-IV $=(2) 3+$ ae + sp, $\mathrm{V}=$ (3) $2+$ ae, $\mathrm{VI}=(4) 2+$ ae, VII $=(5) 2+$ ae + sp, VIII $(6)=1, I X=(7) 2+$ ae, $X(8)=2(1$ spiniform $)+$ ae, $X I$ $(9)=2+$ ae, XII $(10)=2+$ ae, XIII $(11)=2+$ ae, XIV $(12)=2+$ ae, $X V(13)=2+$ ae, XVI $(14)=2+$ ae, XVII $(15)=2+$ ae, XVIII $(16)=2+$ ae, XIX $(17)=$ $2+$ ae, $\mathrm{XX} \quad(18)=2+$ ae, XXI $(19)=2+$ ae, XXII $(20)=1, \operatorname{XXIII}(21)=1, \operatorname{XXIV}(22)=1+1, \operatorname{XXV}(23)=$ $1+1$, XXVI-XXVIII $(24)=5+$ ae.

Antenna (Figure $1 \mathrm{H}$ ) with short coxa bearing plumose seta; basis with two subequal terminal setae; exopod indistinctly 7-segmented with setal formula of $1,2,1,1,1,1,1+3$; endopod 2-segmented, first segment with two unequal subterminal setae; second segment bilobed, with proximal and distal lobes bearing nine and seven setae, respectively.

Table 1. Spine and setal formula of legs $1-5$ of Centropages aegypticus sp. nov.

\begin{tabular}{|c|c|c|c|c|c|c|c|c|}
\hline & \multirow[t]{2}{*}{ Coxa } & \multirow[t]{2}{*}{ Basis } & \multicolumn{3}{|c|}{ Exopod } & \multicolumn{3}{|c|}{ Endopod } \\
\hline & & & 1 & 2 & 3 & $\mathbf{1}$ & 2 & 3 \\
\hline Leg 1 & $0-1$ & $0-1$ & $\mathrm{I}-1$ & $\mathrm{I}-1$ & $\mathrm{II}, \mathrm{I}, 4$ & $0-1$ & $0-2$ & $1,2,3$ \\
\hline Leg 2 & $0-1$ & $0-0$ & $\mathrm{I}-1$ & $\mathrm{I}-1$ & III,I,5 & $0-1$ & $0-2$ & $2,2,4$ \\
\hline Leg 3 & $0-1$ & $0-0$ & I- 1 & $\mathrm{I}-1$ & III,I,5 & $0-1$ & $0-2$ & $2,2,4$ \\
\hline Leg 4 & $0-1$ & $0-0$ & I- 1 & I- 1 ; & III,I,5 & $0-1$ & $0-2$ & $2,2,3$ \\
\hline Leg 5 (Female) & $0-0$ & $1-0$ & & -0 & $\mathrm{II}, \mathrm{I}, 4$ & $0-1$ & $0-1$ & $2,2,2$ \\
\hline
\end{tabular}

Mandible (Figure 1IJ) with eight cuspate teeth and spinulose seta along the coxal cutting edge; basis bearing four medial setae at midlength; exopod 5-segmented with setal formula of $0,1,1,1,2$; endopod 2-segmented, carrying four setae at distal corner of proximal segment and nine setae and two rows of fine spinules anteriorally on distal segment.

Maxillule (Figure $1 \mathrm{~K}$ ) with 15 well-chitinized setae on praecoxal arthrite; coxa bearing seven well developed and short proximal seta on epipodite and three setae on endite; basis completely fused to endopod, exite with seta and first and second endites with four and five setae, respectively; endopod indistinctly 2 -segmented, bearing six setae along the medial margin of proximal segment and three setae on distal segment; exopod with nine lateral setae.

Maxilla (Figure 1L) praecoxal endites with 4, 3 setae, coxal endites with 3, 3 setae, basal endite with two strong and one short slender setae, and endopod with eight setae.

Maxilliped (Figure 2A) with four syncoxal lobes, with 1, 2, 3, 4 setae respectively; basis with spinular row along threequarters of medial margin and bearing three plumose setae distally; endopod 6-segmented, of which first segment almost completely incorporated into basis, with two unequal setae and second to sixth segments bearing 2, 3, 2, $2+1,4$ setae, respectively.

Seta and spine formula of legs 1 to 5 shown in Table 1. Leg 1 basis (Figure 2B) with medial spinulose seta. Legs 2 to 4 (Figure $2 \mathrm{C}-\mathrm{E}$ ) similar to each other except for the number of medial setae on third endopodal segment and longer coxa of leg 4. Leg 5 (Figure $2 \mathrm{~F}$ ) asymmetrical, with 2-segmented exopod and 3-segmented endopod; proximal exopodal segment with incomplete articulation between the two ancestral segments posterolaterally and long sword-like process medially; process of left leg located at three thirds of segment length, thicker and longer than right one, nearly as long as second segment, curved medially, with row of spinules on posterior surface; process of right leg located at midlength of segment, with oblique row of thick spinules; distolateral corner of first endopod segment produced into rounded process.

\section{MALE}

Body (Figure 3A) more slender than female; cephalosome with two pointed conical processes (Figure $3 \mathrm{~A} \& \mathrm{~B}$ ); left posterior process of prosome longer than right. Urosome (Figure $3 \mathrm{C}$ ) four free somites, almost symmetrical except for genital somite with genital aperture located ventrolaterally at posterior rim on left side.

Right antennule (Figure 3D) geniculate, 22-segmented, with terminal segment small but well defined; fusion and armature elements as follows: I $(1)=2+$ ae + sp, II-IV $(2)=3+$ ae + sp, $\mathrm{V}(3)=1+\mathrm{ae}, \mathrm{VI}(4)=2+\mathrm{ae}, \mathrm{VII}$ $(5)=2+$ ae + sp, VIII $(6)=1+$ ae, IX $(7)=2+$ ae, $X$ $(8)=2(1$ spiniform $)+$ ae, XI $(9)=2+$ ae, XII $(10)=2$ $(1$ spiniform $)+$ ae, XIII $(11)=2(1$ spiniform $)+$ ae, XIV $(12)=2+$ ae, $X V(13)=2+$ ae, XVI $(14)=2+$ ae, XVII $(15)=2+$ ae, XVIII $(16)=2+$ ae, XIX $(17)=$ $1+$ ae + process, XX $(18)=1+$ ae, XXI-XIII $(19)=2$ $(1$ rudimentary $)+$ ae + process, XXIV $-\mathrm{XXV}(20)=2+$ 2, XXVI $(21)=1+1$, XXVII-XXVIII $(22)=3+$ ae.

Mouthpart appendages, legs 1 and 2 as in female. Legs 3 and 4 (Figure ${ }_{3} \mathrm{E} \& \mathrm{~F}$ ) asymmetrical with right lateral spines on first and second exopodal segment longer than left ones. 
Leg 5 (Figure $3 \mathrm{G} \& \mathrm{H}$ ) with narrower intercoxal sclerite and wider coxa than of other legs; basis bearing outer seta on subterminal corner; first endopodal segment of both legs produced distolaterally into round process as in female. Left leg 5 (Figure $3 \mathrm{G}$ ) with 2-segmented exopod and 3-segmented endopod; second exopodal segment approximately 1.5 times as long as first segment, proximally with tuft of hair on posterior surface bearing two spines laterally and one spine apically. Right leg 5 (Figure $3 \mathrm{H}$ ) with 3 -segmented rami; first exopodal segment with thick distolateral seta; second exopodal segment with seta at distolateral corner and curved, undulating long medial process bearing hyaline ridge along lateral edge; third exopodal segment with small lateral spine at one-third distance from proximal border and club-shaped thick medial seta, and terminally recurved tip; endopod extending beyond second exopodal segment.

\section{VARIATIONS}

The shape and number of spinule row on the female genital compound somite varied among individuals. For example, some specimens had long but intermittent anterior row dorsolaterally on the left side (Figure 4A \& B), and another one had only a single row (Figure $4 \mathrm{C}$ ). No notable variation was detected among the male specimens except for body length.

\section{ETYMOLOGY}

The specific name of the new species is from the Latin aegypticus and alludes to the Egyptian water from which the new species was collected.

\section{DISCUSSION}

Centropages aegypticus sp. nov. differs from all other congeneric species in the following characters: two pointed processes on the mid-dorsal cephalosome; the female genital compound somite with irregular surface outline swelling on the right side and one or two rows of spinules dorsolaterally on the left side; 2-segmented exopod of the female leg 5; asymmetrical medial processes of the female leg 5, of which the left one is longer and the right one with oblique row of thick spinules; and the third exopodal segment of the male leg 5 with a clubshaped medial seta. Each of these characters is unique to the present species. Two-segmented exopod of the female right leg 5 by fusion of the ancestral first and second segments is also seen in C. tenuiremis Thompson \& Scott, 1903 that is distributed in the Indo-West Pacific (see Chen \& Zhang, 1965; Mulyadi, 1998), but the fusion in both left and right legs has never been reported in the genus. Centropages tenuiremis, $C$. orsinii and C. furcatus have apparently asymmetrical medial processes of the female leg 5 (see Mori, 1937; Mulyadi, 1998), but their longer process is on the right leg in contrast to that on the left leg of C. aegypticus.

Other characteristic features of the new species are: three prominent spines each on the first, second, and fifth antennular segments in both sexes as in C. furcatus and C. typicus Kröyer, 1849; medially-curved medial process on the exopod of the female left leg 5, which is generally straight or curved toward the tip of the segment; the process on the right leg located at midlength of the segment, which is generally at the distal corner of the segment; and the asymmetrical male legs 3 and 4, in which lateral spines on the first and second exopodal segments of the right legs are longer. Some centropagid species have rarely asymmetrical legs other than leg 5. For example, Mori (1937) described C. tenuiremis (as C. yamadai Mori, 1934) as having longer lateral spines on the first and second segments of the male right leg 4 than those of the left leg as in C. aegypticus. Another type of asymmetry is seen in the length of distolateral spine on the third exopodal segment of the male leg 4, which is longer in the right leg than in the left leg, in C. abdominalis Sato, 1913 (Mori, 1937) and C. brevifurcatus Shen \& Lee, 1963 (Shen \& Lee, 1963; Ohtsuka et al., 2003). As far as we know, asymmetry of leg 3 of the present species is first reported in copepods. Asymmetry of legs 3 and 4 is sexually dimorphic, limited to the male, and the longer spine is always on the right leg as the male leg 5 forming a chela to grasp a female for copulation is always the right one. This indicates that the right leg 4 (plus the right leg 3 in C. aegypticus) in these species plays an auxiliary role for copulation.

Vervoort (1964) divided Centropages species into five species groups, namely typicus, furcatus, hamatus, orsinii and violaceus groups according to the shape of the last thoracic somite, shape of abdomen, morphology of leg 5 and the male antennule (cf. McKinnon \& Kimmerer, 1988). Subsequently, Ohtsuka et al. $(2003,2005)$ recognized two other groups, trispinosus and alcocki. In spite of many unique characters of C. aegypticus, it is similar to C. tenuiremis of the hamatus group in the following characters common to the two species: shape of pointed prosome ends and relatively long caudal rami in both sexes; 2-segmented exopod of the female leg 5; medial process of exopod of the female right leg 5 located nearly at midlength of the segment; asymmetry in female leg 5 and the male leg 4; and absence of distomedial spine on distal exopodal segment of the male left leg 5, which is the character used by Ohtsuka et al. (2005) to distinguish the alcocki group. However, the exopod of the right leg 5 of the $C$. aegypticus male, which has an undulating long medial process on the second segment and recurved tip of the somewhat S-shaped third segment, is apparently different from that of the hamatus group, which includes C. hamatus (Lilljeborg, 1853), C. kroyeri Giesbrecht, 1892, C. ponticus, C. tenuiremis, C. abdominalis Sato, 1913 (Vervoort, 1964) (Ohtsuka et al. (2003) moved C. trispinous Sewell, 1914 from this group). This indicates that $C$. aegypticus does not belong to the hamatus groups in spite of the similarity to C. tenuiremis. One may consider C. dorsispinatus Thompson \& Scott, 1903 of the typicus group as another similar species because both species have a prominent dorsal spine on both the female and male cephalosome. However, C. dorsispinatus has a single spine at the posterodorsal margin of the cephalosome instead of two short spines on the mid-dorsal region of the cephalosome in C. aegypticus. The spine of the C. dorsispinatus is undoubtedly homologous to a small knob on the same position of $C$. aegypticus and therefore these dorsal spines do not indicate their relationship. No other species are as similar as $C$. tenuiremis. In conclusion, the new species does not belong to existing species groups, nor does it comprise a new group.

\section{ACKNDWLEDGEMENTS}

We are grateful to anonymous referees for their valuable suggestions. The first author would like to thank 'The Partnership for Observation of the Global Oceans' (POGO), for their 
financial support to cover his visit to the second author's former laboratory at the Center for Marine Environmental Studies, Ehime University, Japan. Thanks are also due to the Marine Science Department staff, Suez Canal University, for their support and help during field work.

\section{REFERENCES}

Aamer M.A., El-Sherbiny M.M., Gab-Alla A.A. and Kotb M.M. (2006) Studies on the ecology of zooplankton standing crop of Sharm El-Maiya Bay, Sharm El-Sheikh, northern Red Sea, Egypt. Catrina 1, $73-80$.

Boxshall G.A. and Hasley S.H. (2004) An introduction to copepod diversity I. London: The Ray Society.

Bradford-Grieve J.M. (1999) The marine fauna of New Zealand: pelagic calanoid Copepoda: Bathypontiidae, Arietellidae, Augaptilidae, Heterorhabdidae, Lucicutiidae, Metridinidae, Phyllopodidae, Centropagidae, Pseudodiaptomidae, Temoridae, Candaciidae, Pontellidae, Sulcanidae, Acartiidae, Tortanidae. NIWA Biodiversity Memoir 111, 1-268.

Bradford-Grieve J.M., Markhaseva E.L., Roch C.E.F. and Abiahy B. (1999) Copepoda. In Boltovskoy D. (ed.) South Atlantic zooplankton, Leiden: Backhuys Publishers, pp. 869-1098.

Brodsky K.A. (1950) Calanoida of the Far Eastern Seas and Polar Basin of the USSR. Moskva-Leningrad: Izdatel'stvo Akademii Nauk SSSR. [English translation: Israel Programme for Scientific Translations, Jerusalem, 1967.]

Chen Q.-C. and Zhang S.-Z. (1965) The planktonic copepods of the Yellow Sea and the East China Sea. I. Calanoida. Studia Marina Sinica 7, 20-131. [In Chinese with English abstract.]

El-Sherbiny M.M. (1997) Some ecological studies on zooplankton in Sharm El-Sheikh (Red Sea). MSc thesis, University of Suez Canal, Ismailia, Egypt.

Halim Y. (1969) Plankton of the Red Sea. Oceanography and Marine Biology: an Annual Review 7, 231-275.

McKinnon A.D. and Kimmerer W.J. (1988) A new species of calanoid copepod from Shark Bay, Western Australia. Record of the Western Australian Museum 14, 171-176.
McKinnon A.D. and Dixon P. (1994) Centropages acutus, a new calanoid copepod from the Fly River Estuary, Papua New Guinea. The Beagle 9-14.

Mori T. (1937) The pelagic Copepoda from the neighboring waters of Japan. Tokyo: The Soyo Co. Inc.

Mulyadi (1998) New records and taxonomic reexamination of the genus Centropages (Copepoda: Calanoida), with notes on their geographic distribution in Indonesian waters. Raffles Bulletin of Zoology 46, $53-70$.

Ohtsuka S., Itoh H. and Mizushima T. (2005) A new species of the calanoid copepod genus Centropages (Crustacaea) collected from Shimizu Port, Middle Japan: introduced or not? Plankton Biology and Ecology $52,92-99$.

Ohtsuka S., McKinnon D., Pinkaew K., Putchakarn S. and Chalermwat K. (2003) New record of Centropages brevifurcus (Crustacea: Copepoda: Calanoida) from the Gulf of Thailand and its full redescription. Species Diversity 8, 67-78.

Razouls C. (1995) Diversité et répartition géographique chez les copépodes pélagiques. 1. Calanoida. Annales de l'Institut Océanographique 71, 81-401.

Shen C. and Lee F. (1963) The estuarine Copepoda of Chiekong and Zaikong Rivers, Kwaingtung Province, China. Acta Zoologica Sinica 15, 571-596. [In Chinese with English abstract.]

and

Vervoort W. (1964) Notes on two Pacific species of Centropages (Copepoda, Calanoida), C. australiensis Fairbridge, 1944, and C. aucklandicus Krämer, 1895. Crustaceana 7, 293-311.

Correspondence should be addressed to: Mohsen M. El-Sherbiny Marine Science Department Faculty of Science, Suez Canal University Ismailia-41522 Egypt email: mohsenrussia@yahoo.com 